\title{
The Somosaguas palaeontology project: an envision of Nieves López Martínez for linking science and society
}

\author{
Omid FESHARAKI ${ }^{*}$, Angélica TORICES ${ }^{2}$, Blanca A. GARCÍA YELO ${ }^{1,3}$, Natalia TEJEDOR \\ NAVARRO ${ }^{4}$ Lucía de la OSSA ${ }^{1} \&$ Manuel HERNÁNDEZ FERNÁNDEZ ${ }^{1,5}$
}

\begin{abstract}
'Departamento de Paleontología, Universidad Complutense de Madrid, José Antonio Novais 2, 28040 Madrid, Spain; omidfesharaki@hotmail.com; lucia.ossa14@gmail.com

${ }^{2}$ Department of Biological Sciences. Faculty of Science, CW405 Biological Sciences Building, Edmonton, Alberta, T6G 2E9, Canada; atorices@hotmail.com

${ }^{3}$ Departamento de Paleobiología, Museo Nacional de Ciencias Naturales (CSIC), Madrid, Spain; blancayelo@hotmail.com

${ }^{4}$ Escuela de Trabajo Social, Universidad Complutense de Madrid, Campus de Somosaguas, 28223 Pozuelo de Alarcón, Madrid, Spain; natalia271190@hotmail.com

${ }^{5}$ Departamento de Cambio Medioambiental, Instituto de Geociencias (UCM,CSIC), José Antonio Novais 2, 28040, Madrid, Spain; hdezfdez@geo.ucm.es

* Corresponding author
\end{abstract}

Fesharaki, O., Torices, A., García Yelo, B.A., Tejedor Navarro, N., de la Ossa, L. \& Hernández Fernández, M. 2012. The Somosaguas palaeontology project: An envision of Nieves López Martínez for linking science and society. [El Proyecto Somosaguas de paleontología: Una visión de Nieves López Martínez para conectar ciencia y sociedad]. Spanish Journal of Palaeontology, 27 (2), 83-92.

Manuscript received 30 April 2012

Manuscript accepted 21 September 2012

(C) Sociedad Española de Paleontología ISSN 2255-0550

\section{ABSTRACT}

The palaeontological site of Somosaguas is located in Pozuelo de Alarcón, to the west of the city of Madrid (Spain), and contains fossils of Miocene age corresponding to 24 species of micro- and macromammals as well as other vertebrates. The Somosaguas Palaeontology Project is focused on this site and was coordinated by Nieves López Martínez between 1998 and 2010 as an example of management of a palaeontological site by university students and young researchers. This project began with fi eld seasons for students in natural sciences grades and today is a multidisciplinary project open to students from any university degree. The signifi cance of the investigations around this fossil site is refl ected in a large number of papers published in national and international journals. Additionaly, there are numerous outreach activities in geology and palaeontology with special attention to what we call Social Palaeontology. Finally, this project has a strong

\section{RESUMEN}

El yacimiento paleontológico de Somosaguas se localiza en Pozuelo de Alarcón, al oeste de la ciudad de Madrid (España), y contiene fósiles de edad miocena correspondientes a 24 especies de micro- y macromamíferos, así como otros vertebrados. El Proyecto Somosaguas de Paleontología se centra en el mismo y fue coordinado por Nieves López Martínez entre 1998 y 2010 como un ejemplo de gestión de un yacimiento paleontológico por parte de estudiantes universitarios y jóvenes investigadores. Este proyecto comenzó con campañas de campo para los estudiantes de las carreras de ciencias naturales y hoy es un proyecto multidisciplinar abierto a estudiantes de cualquier disciplina. La importancia de las investigaciones en torno a este yacimiento se refleja en un gran número de artículos publicados en revistas nacionales e internacionales. Adicionalmente, existen numerosas actividades de divulgación geológica y paleontológica, con 
commitment to educational innovation in both non-formal (during school visits, open days at the site and science fairs) and formal university education, with the establishment of an introduction to investigation group in order to prepare young researchers in different fields of geology, palaeontology and education.

Keywords: Social Palaeontology, educational innovation, palaeontological excavation, scientific outreach, scientific research.

\section{INTRODUCTION}

In 1998 Miocene vertebrate fossils were discovered near the Faculty of Political Sciences at the Complutense University of Madrid (UCM) located in Pozuelo de Alarcón, Madrid, Spain (López-Martínez et al., 2000a). The site of Somosaguas is situated in the western part of the Madrid Basin and consists of two superposed fossiliferous strata (T1 and T3) with a barren unit between them (T2). The lower unit (T1) consists of a mud flow deposit with abundant clayey arkoses and vertebrate remains of middle Aragonian age (López-Martínez et al., 2000b; Luís \& Hernando, 2000; Hernández Fernández et al., 2006; Perales et al., 2009). The unit T2 presents an alternation of micaceous sandy levels produced by sheet flood processes and brown clays levels produced by decantation on a waterlogged environment (Mínguez Gandú, 2000; Fesharaki, 2005). The upper unit (T3) is formed by an amalgamated deposit of coarse arkoses and microconglomerates produced by debris flow that present traces of macrovertebrates in different states of taphonomic preservation (Polonio \& López-Martínez, 2000; Hernández Fernández et al., 2006).

Since the discovery of the fossil site, Professor of Palaeontology Dr. Nieves López Martínez supervised spring field seasons and the research associated to the discoveries. Palaeontological and geological research has been carried out in addition to the systematic excavation of the sites. But what really stands out in the Somosaguas Palaeontology Project is that Nieves López Martínez relied since the beginning on students and young researchers from the university to perform all the tasks related to the site and its management (López-Martínez et al., 2005). Nowadays, a large group of researchers, instructors and former students that began their careers with this project are responsible for the new field seasons and have extended the activities of this project to outreach activities and educational innovation. The aim of this paper is to present the different tasks that have been carried out in the last especial atención a lo que llamamos Paleontología Social. Finalmente, este proyecto tiene un fuerte compromiso con la innovación educativa tanto en un entorno no formal (durante visitas escolares, jornadas de puertas abiertas en el yacimiento y ferias científicas), como en la educación formal universitaria, con el establecimiento de un grupo de introducción a la investigación cuyo objetivo es preparar jóvenes investigadores en diferentes campos de la geología, la paleontología y la educación.

Palabras clave: Paleontología Social, innovación educativa, excavación paleontológica, divulgación científica, investigación científica.

\section{FIELD SEASONS}

The systematic excavation of the remains of macrovertebrates at the site of North Somosaguas has been carried out in grids of $1 \times 1$ meters (Figs. 1a-1c). In the same campaigns, sediment has been collected for processing and subsequent picking, resulting in the finding of high number of microvertebrates remains. So far more than 6,000 fossils have been obtained (1,150 identifiable remains). These remains belong to 24 mammalian species as well as to other terrestrial vertebrates (Hernández Fernández et al., 2006; Perales et al., 2009). From 1998 to 2004 the annual excavation (usually two weeks in spring) was carried out by senior students from the faculties of Geology and Biology of the UCM. However, the peculiar accessibility features of the site, palaeontological richness and particular taphonomic characteristics make Somosaguas a good place to conduct methodical excavation practices for students from different educational levels. For that reason, since 2004, the participation of students from any faculty at the Complutense University is allowed in excavations (LópezMartínez et al., 2005; Castilla et al., 2009). Nowadays more than 800 students from 15 different degrees have participated in the excavations (Fig. 2a). One of the most important achievements on this project has been to keep the excavations operational regardless of the degree of funding received by the public (UCM, CAM, SEPCYTFECYT and National Plan $\mathrm{I}+\mathrm{D}+\mathrm{I}$ ) and private (Repsol, Geosfera and EDNYA) institutions (Fig. 2b).

During the field season of 2007, students attending the excavations were asked to complete background questionnaires. These questionnaires showed serious deficiencies in the knowledge of important concepts such 

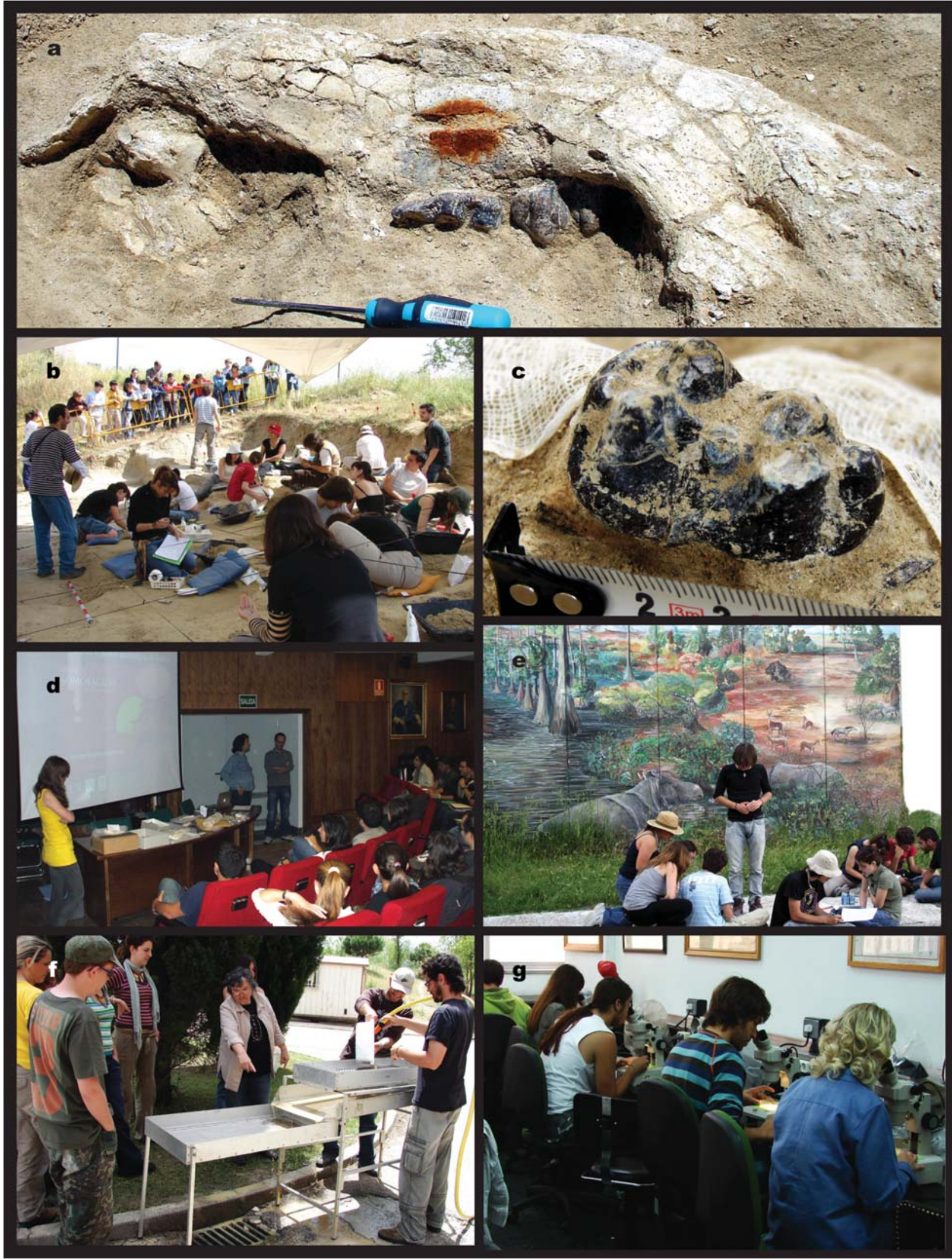

Figure 1. Different aspects of activities carried out in the Somosaguas Palaeontology Project: a) Right hemimandibula of Gomphotherium; b) macrovertebrate excavation in 1x1 grids; c) Gomphotherium molar; d) seminar on techniques of excavation and geology-palaeontology of Somosaguas site; e) students solving geological problems and exercises next to the mural painting that reconstructs the landscape of Somosaguas; $\mathbf{f}$ ) Nieves López leading the students in the activity of washing-sieving the sediment to obtain samples; g) laboratory work for the microfossil picking. 


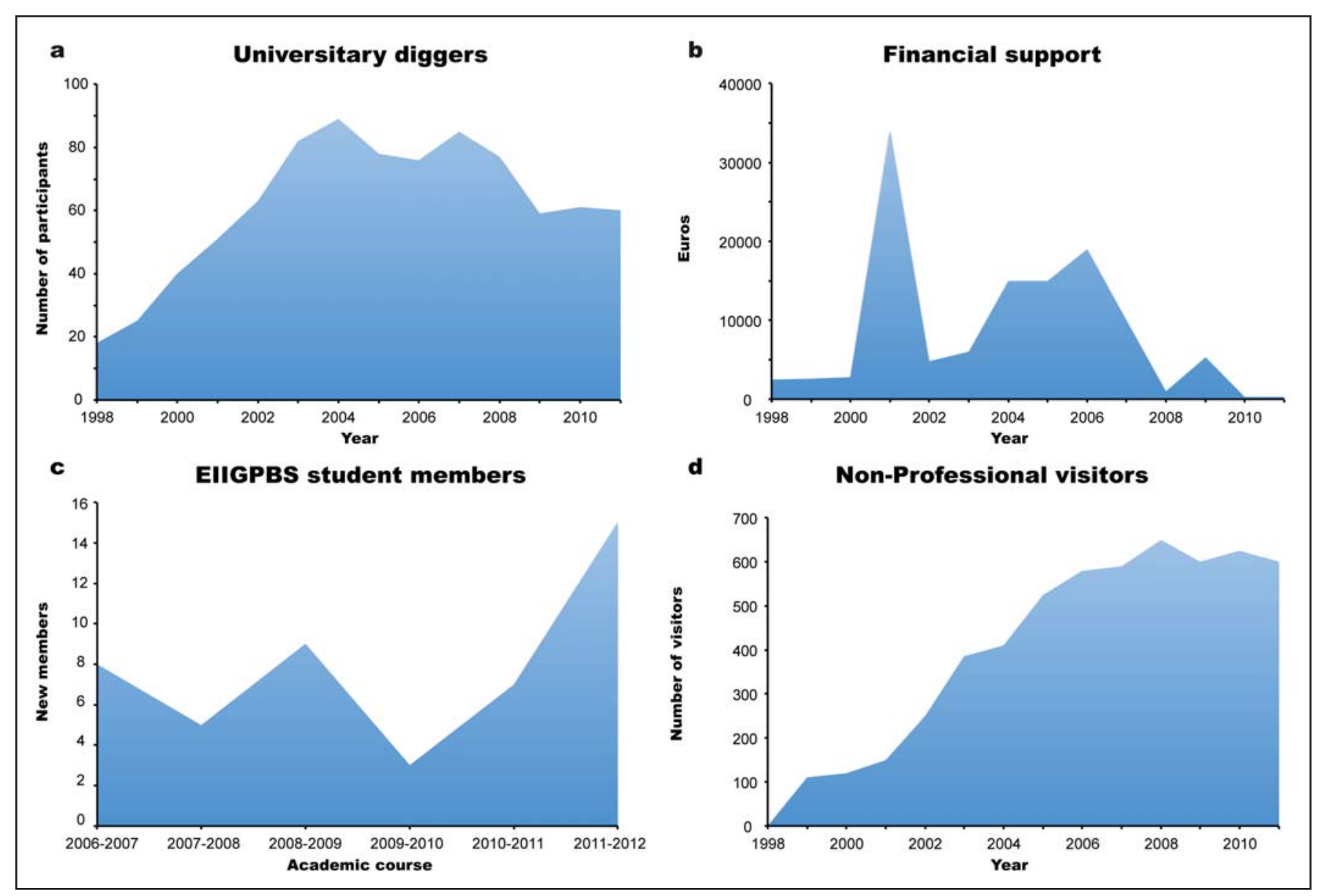

Figure 2. a) Variation of the number of students involved in the excavations between 1998 and 2011; b) funding received by the excavations over the past 14 years; c) number of new students who enter each course in the Team of Introduction to GeoPaleoBiology Research on Somosaguas; d) number of visitors to the Somosaguas Open Days and scientific fairs.

as fossil, fossilization and geological time, among other (Castilla \& De la Iglesia, 2008). For this reason students are taught about the geology and palaeontology of the site and excavation techniques. Moreover, instructors reinforce basic knowledge on palaeontology (fossilization, geologic time, etc.) and geology (numerical and graphical scales, mapping, etc.) applied to the geo-palaeontological environment of the Madrid Basin. Every year, prior to the field season, a theoretical seminar is programmed to explain the geology and palaeontology of the Madrid Basin and Somosaguas site. During the seminar, students can also observe some of the most important fossil pieces restored (Fig. 1d). During the field season students have the opportunity to learn different geological and palaeontological techniques. All students complete the general mapping of the site and several stratigraphic columns solving different geological problems and exercises (Fig. 1e); they learn how to develop a methodical excavation in grids and how to locate, label, consolidate and protect the excavated remains. Collection of sediment from productive levels is also accomplished, followed by washing-sieving the sediment to obtain samples (Fig. 1f), which will be used in the laboratory for microfossil picking (Fig. 1g). Finally, during some campaigns, students have been involved in prospection of new fossiliferous areas and opening of trenches in productive levels.

\section{SCIENTIFIC PRODUCTION}

The scientific work around the Somosaguas site experienced a significant boost in 2000, when 10 studies were published in the journal "Coloquios de Paleontología". During the following years this productivity decreased and the work of the team focused on the field seasons and scientific outreach of the project. Nevertheless, since 2006 new research papers have been published in peer-rewieved national and international journals to account for more than 30 papers. Additionally, numerous contributions have been presented at meetings and conferences. Several academic works have been done: 6 Advanced Studies Diplomes, a chapter of a dissertation thesis (Domingo, 2008) and a PhD Thesis that nowadays is in development. Finally, students 
have done different works related to Somosaguas, under the supervision of Professor Nieves López Martínez, for the final year subject of Vertebrate Paleontology. These works deal with a variety of fields: systematic palaeontology and biochronology (López-Martínez et al., 2000a, 2000b; Luís \& Hernando, 2000; Mazo, 2000; Salesa \& Morales, 2000; Salesa \& Sánchez, 2000; Sánchez, 2000; Van der Made \& Salesa, 2004; Cárdaba et al., 2006; Belaústegui, 2007; Menéndez Gamella et al., 2010; Pérez-García, in press), taphonomy (Cuezva \& Élez, 2000a, 2000b; Polonio \& López-Martínez, 2000; Luís, 2003), palaeopathologies (Sala-Burgos et al., 2007), stratigraphy and sedimentary environments (Minguez Gandú, 2000; Cuevas-González, 2005; Élez, 2005; Fesharaki, 2005; Cuevas-González \& Élez, 2006; Díez-Canseco et al., 2012), petrology, mineralogy and crystalchemistry (Fesharaki, 2005; Fesharaki et al., 2007; Casado et al., 2011), palaeoclimatic and palaeoenvironmental studies (Cuevas-González, 2006; Hernández Fernández et al., 2006; Carrasco et al., 2008; Domingo et al., 2009, 2010, 2012; Perales et al., 2009; Álvarez-Sierra et al., 2011), palaeoecology and palaeobiogeography (Hernández Fernández et al., 2003; Domingo et al., 2007; Pina et al., 2008; García Yelo et al., 2010; Torroba et al., 2010), evolution (Pérez González et al., 2009; Ansón \& Hernández Fernández, in press) and outreach and teaching innovation (Torices et al., 2004; López-Martínez et al., 2005; Castilla et al., 2006, 2009; Sala-Burgos \& Gil-Pita, 2006; Cuevas-González et al., 2008; Benítez López et al., 2009; De la Ossa et al., in press).

\section{UNIVERSITY STUDIES AND THE TEAM OF INTRODUCTION TO GEOPALAEOBIOLOGY RESEARCH ON SOMOSAGUAS}

During the years 2004-2008 there was a progressive decrease in the number of university students in the area of Natural Sciences, while the number of those students interested in the Somosaguas palaeontological excavations grew. In view of this success, and with the intention of making research more accessible to students while completing their university studies, the Team for the Introduction to GeoPalaeoBiological Research in Somosaguas (EIIGPBS) was born in March 2007, as an integral part of the Somosaguas Palaeontology Project. Within this framework researchers of the project instruct each year several students who had attended the excavations and had an interest in further research on Palaeontology, Geology or Education-Outreach (Benítez-López et al., 2009). Students learn how to do bibliographic search, use certain instrumental techniques, data analysis, presentation of results at conferences and scientific seminars, and write research papers. These activities prepare students for future research and even allow the development of certain attitudes and skills that will serve to improve their academic performance. Figure $2 \mathrm{c}$ shows the variation in the number of students that have participated in EIIGPBS every year. The works carried out so far are varied and range from issues directly related to geology and paleontology of the Somosaguas site and surroundings (Carrasco et al., 2008; Pina et al., 2008; Perales et al., 2009; Pérez González et al., 2009; Menéndez Gamella et al., 2010; Torroba et al., 2010; Ansón \& Hernández Fernández, in press), to research and educational innovation (Castilla \& De la Iglesia, 2008; Benítez-López et al., 2009; De la Ossa et al., in press) in various fields of science (Casado et al., 2011). Many students who have collaborated with the EIIGPBS have monitored the excavations in subsequent years and are involved in open days, where the general public has access to outreach activities about the discoveries around the site. The collaboration of these students allows senior researchers to focus on more comprehensive training of new excavators and EIIGPBS students develop other aspects important for a researcher, such as the ability to divulgate knowledge to non-specialists in sciences (Figs 3a$3 b)$. Since the EIIGPBS is a multidisciplinary team, there are seminars and field trips in which researchers explain instrumental techniques, software or new developments in their field. This active exchange of expertise and experiences allows other team members to expand greatly their range of knowledge.

Finally, there have been a number of works carried out by university students not formally related to the EIIGPBS team which have been an innovation in the form of proposing works for undergraduate courses or final projects; among others we can mention the work of Cristina Mateos Casado (student of Sociology) on the sociological aspects of a palaeontological dig, or the works of final year students of Architecture about solutions for buildings that suit and protect the environment of the paleontological site of Somosaguas (Gutiérrez Cabrero, pers. comm. 2012).

\section{OUTREACH}

The Somosaguas Palaeontology Project is one of the pioneering projects in Spain in the outreach of palaeontology at all society levels (Cuevas-González et al., 2008). Such outreach has several aspects: the broadcast media, outreach in non-university education (schools and colleges), outreach to the general public, and finally what we call Social Palaeontology (Torices et al., 2004). 


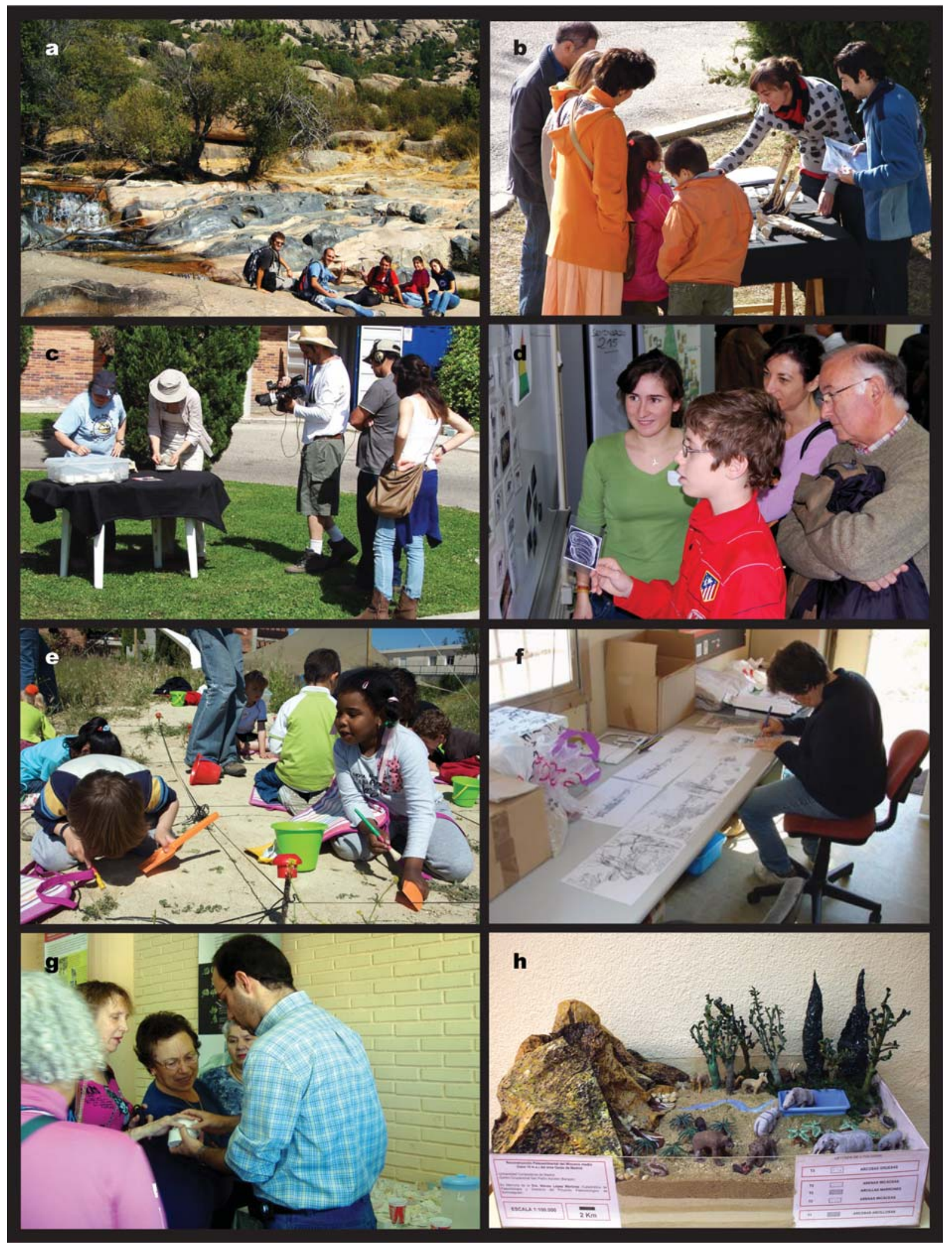

Figure 3. a) Monitors leading EIIGPBS students during the field trips; b) EIIGPBS monitors and students explaining the palaeontology of Somosaguas site during the Open Days; c) Nieves López showing some of the fossil samples of the site for a TV report; d) a family plays during the Madrid Science Fair to join cards with molar types and alimentation behaviour; e) young researchers are initiated at Somosaguas palaeontological site during the school visits; f) Nieves López sketching for the development of the mural painting; g) a monitor explains the palaeontology of Somosaguas to a group of visitors with varying degrees of blindness; $\mathbf{h}$ ) scale model that simulates the faunas and landscape of Madrid during the Miocene (see text for more details). 


\subsection{Broadcast media}

Since the discovery of the site in 1998, it has been subject of interest for the educational community and the general public, as evidenced by numerous articles in local and national newspapers and magazines. Additionally, the activities in the fossil site have appeared on several television talk shows, as well as a documentary made by students of the Faculty of Journalism about the excavations and site management (Fig. 3c). Finally, we have developed a specific multimedia channel in the Complumedia website of the Complutense University of Madrid (http:// complumedia.ucm.es/canal.php? p1=paleosomos), which is based on the activities of the Somosaguas Palaeontology Project. The videos made during the excavations, the microfossil picking sesions, and the restoration processes of the extracted remains were recorded by Ana Cuerva, member of the Somosaguas Palaeontology Project and former student of Information Sciences, and have both educational and divulgative purposes.

As an example of the commitment of the Somosaguas Palaeontology Project to the use of new technology of information in the academic world, a blog based on the research by the EIIGPBS was released in 2007 (http:// investigacionensomosaguas.blogspot.com). Since then this blog carried out an important part of the outreach activity keeping updated the growing number of followers of the excavation. Moreover, this blog has proven as the best way to expose the project at international level, which is reflected in the more than 10,000 visits received every year from more than 40 countries. Due to the growing number of people who are getting connected to news and information through the developing social networks, we have also created a page of the Somosaguas Palaeontology Project in Facebook (http://www.facebook.com/pages/ Proyecto-Somosaguas-de-Paleontología/254024151311219).

\subsection{Outreach in non-university education}

The non-formal learning that takes place in the area of schools and high schools in relation to palaeontology activities must have several characteristics (Castilla et al., 2006): it should be flexible to accommodate all levels of knowledge, it has to be practical to motivate students to learn and research; it must be participatory and inclusive so that each individual feels fulfilled and interacts with the rest of the group; it should follow a methodology of action-reflection, in which each learned concept is more easily internalized and used in practical work following a rotation system that allows all students to integrate in the dynamics of a paleontological excavation for a few hours and feel like a detective of Earth's past (Figs 3d-3e).

Since the year 1999 Somosaguas Palaeontology Project has pursued doing outreach works in palaeontology divulgating the paleontological site richness as a social, natural and cultural heritage in education levels below university. This is fulfilled during each field season in which students from several schools visit the site and can see the works being done on it. Depending on their age they participate in some of these tasks or learn through play certain aspects of the geology and palaeontology of the community (Castilla et al., 2009). Moreover, throughout the year schools and high schools can participate in activities around the site, guided by instructors from a company of environmental education (EDNYA), which has an agreement with the Complutense University to continue throughout the year these outreach efforts focusing on programs of education on natural sciences in the Somosaguas site. Furthermore, the Somosaguas Palaeontology Project has initiated recently several courses for the training of monitors in this type of outreach activities. The success of this program has been proven since some of the high school level students, visiting the site and taking part in the activities, have subsequently pursued Geology studies and have been integrated into the EIIGPBS team.

\subsection{Outreach to the general public}

General public is allowed to visit the excavation during the open days of the field season (two mornings during the weekends) and during the Madrid for Science Fairs, Natura Fairs and Weeks of Science organized in Madrid by different institutions (Fig. 2d). During these days we hand out stickers, informative leaflets, Gomphotherium models, didactic CDs to the visitors and especially to school students and teachers.

During those days or weeks of science different games, exhibitions and talks are organized to expose various palaeontological and geological aspects of the site and the Madrid Basin (Castilla et al., 2006, 2009). Some years concurrently with important anniversaries as the centenary of the discoveries of Charles Darwin and the International Year of Biodiversity the content of the presentations for both the general public and university students are adjusted; so visitors can learn and appreciate the importance of preservation of nature and the paleontological sites as natural and cultural heritage.

Groups of senior citizens often accompanied by their children and grandchildren have transformed the open days of the site in true palaeontology and geology workshops in family. During these open days there is a time for both learning through scientific activities and socialization and for valuing the work of the researchers involved in the Project (Figs 3b-3e). Also the unemployed have been a source of increasing visitors due to the importance of continuous learning as one of the options to improve the chances of returning to the labor market.

Some of the research papers that have described the environment and climate prevailing in Somosaguas 14 
million years ago have been used by Cristina Díaz, Sergio Pérez and Nieves López Martínez to make a mural painting of 3 by $15 \mathrm{~m}$, held at the site itself reconstructing the landscape of Somosaguas. This mural painting is another mean of outreach that has turned an ordinary place into a unique place where anyone can contemplate how Madrid landscape was 14 Myr ago (Fig. 3f; see also Fig. 1e).

\subsection{Social palaeontology}

With this name Torices et al. (2004) designated the work of the Somosaguas Palaeontology Project in the outreach of palaeontology for groups with special educational needs. Castilla et al. $(2006,2009)$ summarized the activities in this field so far, although new activities have been designed and the groups implied have increased (Fig. $3 \mathrm{~g}$ ). It is interesting to note that this developing field has received international attention, especially in Latin America (Hernández Fernández, 2008; González et al., 2011).

Our last action on this ground has involved the union between two fields of the project, the social outreach and the training of young researchers. Two members of the EIIGPBS Education group have worked in 2011 with students from the San Pedro Integrated Center of Barajas (Madrid), who present different degrees of psichical discapacity and therefore have special educational needs. The project consisted in the realization of a paleoreconstruction model with clay figures representing the environment and wildlife of the Middle Miocene in Madrid (Fig. 3h; De la Ossa et al., in press).

\section{CONCLUSIONS}

The work undertaken by this project over the past 14 years and the reception given by the society, and especially by the educational community (professors and students from several Spanish universities), shows the possibility of using certain paleontological sites as true centers for diffusion of scientific knowledge and outreach to the general public. This would allow Society to feel the work of scientists as its own and appreciate their value. On the other hand these projects allow raising awareness of the importance of the preservation of paleontological sites as cultural, social and natural heritage.

\section{ACKNOWLEDGEMENTS}

This work is in memory of Nieves López Martínez, who allowed a group of young researchers to undertake the management of a unique project in a vertebrate site and that every day covers more areas in the scientific and educational outreach. The authors wish to thank all students and researchers who have collaborated during all these years in the Somosaguas Palaeontology Project; their work has allowed this project to grow more and more every year. The quality of this manuscript improved thanks to the insightful reviews of Laura Domingo Martínez and Juán López Cantalapiedra. This work is a contribution of the PMMV team (Palaeoclimatology, Macroecology and Macroevolution of Vertebrates) as part of the UCM 910607 Research Group on Evolution of Cenozoic Mammals and Continental Palaeoenvironments. It has been partially funded by MINECO (CGL2011-25754), MICINN (CGL2010-19116/BOS, CGL2008-05813-C0201/BTE) and UCM (UCM-BSCH GR58/08-910607) projects. Blanca García Yelo is a researcher in training by a FPU contract (Education Ministry of Spain). Angelica Torices is funded by FECYT and the program "Ayudas para la movilidad postdoctoral en centros extranjeros".

\section{REFERENCES}

Álvarez-Sierra, M.A., Domínguez Alonso, P., Fernández Marrón, M.T., García-Paredes, I., Gómez Cano, A.R., Goy, A., Hernández Fernández, M. \& López-Guerrero, P. 2011. Episodios Críticos en la Historia de la Tierra. In: Primera Reunión Científica del Instituto de Geociencias (eds. Pérez-Monserrat, E.M. \& Charco, M.). Instituto de Geociencias (CSIC-UCM), Madrid, 59-68.

Ansón, M. \& Hernández Fernández, M. in press. Artistic reconstruction of the appearance of Prosantorhinus Heissig, 1974, the teleoceratine rhinoceros from the middle Miocene of Somosaguas. Spanish Journal of Palaeontology.

Belaústegui, Z. 2007. Amphicyon, un carnivoro gigante del Aragoniense de Somosaguas (Pozuelo de Alarcón, Madrid). In: Cantera Paleontológica (eds. Cambra Moo, O., Martínez Pérez, C., Chavero Macho, B., Escaso Santos, F., Esteban de Trivigno, S. \& Marugán Lobón, J.). Diputación Provincial de Cuenca, Castilla la Mancha, 73-80.

Benítez-López, G., Fesharaki, O., Gómez Cano, A.R. \& Pérez de los Ríos, M. 2009. Equipo de Introducción a la Investigación GeoPaleoBiológica en Somosaguas: Un nuevo enfoque para el aprendizaje de la investigación. Paleolusitana, 1, 105-113.

Cárdaba, J.A., Cuevas-González, J., Élez, J., Fesharaki, O., Hernández Fernández, M., López-Martínez, N., Morales, J., Sala-Burgos, N. \& Salesa, M.J. 2006. Revisión de la fauna de vertebrados fósiles de Somosaguas (Mioceno medio, Pozuelo de Alarcón, Madrid). XXII Jornadas de la Sociedad Española de Paleontología, Abstract Book, p. 94-95.

Carrasco, A., Sacristán, S., Benítez-López, G., RomeroNieto, D., Fesharaki, O. \& López-Martínez, N. 2008. Aplicaciones paleoclimáticas y paleoambientales de los estudios mineralógicos al yacimiento de vertebrados miocenos de Somosaguas. In: Palaeontologica Nova (eds. 
Esteve, J. \& Meléndez, G.). Publicaciones del Seminario de Paleontología de Zaragoza, 8, 135-149.

Casado, A.I., Fesharaki, O. \& Pérez-García, A. 2011. Origen de la vida: evolución de las teorías hacia un inicio organizado por minerales. In: Viajando a mundos pretéritos (eds. Pérez-García, A., Gascó, F., Gasulla, J.M. \& Escaso, F.). Ayuntamiento de Morella, Castellón, 75-92.

Castilla, G. \& De la Iglesia, A. 2008. ¿Qué saben de paleontología los estudiantes universitarios? In: Palaeontologica Nova (eds. Esteve, J. \& Meléndez, G.). Publicaciones del Seminario de Paleontología de Zaragoza, 8, 165-173.

Castilla, G., Fesharaki, O., Hernández Fernández, M., Montesinos, R., Cuevas-González, J. \& López-Martínez. N. 2006. Experiencias educativas en el yacimiento paleontológico de Somosaguas (Pozuelo de Alarcón, Madrid). Enseñanza de las Ciencias de la Tierra, 143, 265-270.

Castilla, G., López-Martínez, N., Hernández Fernández, M., Fesharaki, O., Cárdaba, J.A., Cuevas-González, J., Élez, J., Raúl Montesinos, R., Pérez-González, S., Sala-Burgos, C., Sala-Burgos, N., Salesa, M.J. \& Torices, A. 2009. Actividades educativas en el yacimiento de vertebrados miocenos de Somosaguas (Universidad Complutense, Pozuelo de Alarcón, Madrid). In: Notas para la Historia Reciente del Museo Nacional de Ciencias Naturales: homenaje a $M^{a}$ Dolores Soria Mayor (eds. Lobón, J. \& Morales, J.). Monografías del Museo Nacional de Ciencias Naturales (CSIC), Madrid, 24, 339-415.

Cuevas-González, J. 2005. Estado actual de los conocimientos paleontológicos y estratigráficos de los yacimientos aragonienses de Somosaguas (Pozuelo de Alarcón, Madrid). Coloquios de Paleontología, 55, 103-123.

Cuevas-González, J. 2006. Estudio isotópico de ${ }^{13} \mathrm{C} y{ }^{18} \mathrm{O}$ en sedimentos y fósiles de los yacimientos de Somosaguas del Mioceno medio (cuenca de Madrid). Diploma de Estudios Avanzados, Universidad Complutense de Madrid (unpublished).

Cuevas-González, J. \& Élez, J. 2006. Arquitectura deposicional de un depósito aluvial basada en la distribución de fósiles de vertebrados del Mioceno de Somosaguas (Madrid). XXII Jornadas de la Sociedad Española de Paleontología, Abstract Book, p. 110.

Cuevas-González, J., Domingo, L. \& Fesharaki, O. 2008. Yacimientos de Somosaguas: de la investigación paleontológica a un aula didáctica. In: Palaeontologica Nova (eds. Esteve, J. \& Meléndez, G.). Publicaciones del Seminario de Paleontología de Zaragoza, 8, 425-431.

Cuezva, S. \& Élez, J. 2000a. Estudio preliminar de la microestructura de los huesos fósiles de mamíferos de Somosaguas (Pozuelo de Alarcón, Madrid, España). Coloquios de Paleontología, 51, 137-158.

Cuezva, S. \& Élez, J. 2000b. Reconocimiento del estadio de desarrollo en la microestructura de los huesos fósiles de mamíferos (Somosaguas y Layna). Coloquios de Paleontología, 51, 159-174.

De la Ossa, L., Tejedor-Navarro, N. \& Fesharaki, O. in press. Experiencias durante la construcción de un diorama del Mioceno de Somosaguas por parte de alumnos con necesidades educativas especiales. Enseñanza de la Ciencias de la Tierra.

Díez-Canseco, D., López-Martínez, N., Díaz-Molina, M. \& Benito, M.I. 2012. Stream mouth deposits in the paleontological site of Somosaguas, middle Miocene, Madrid basin. Spanish Journal of Palaeontology, 27, 93-104.

Domingo, L. 2008. Inferencias Paleoclimáticas y Paleoambientales en Periodos Críticos mediante Análisis Geoquímicos del Registro Geológico Continental. PhD Thesis, Universidad Complutense de Madrid (unpublished).

Domingo, L., Cuevas-González, J., Grimes, S.T., Hernández Fernández, M. \& López-Martínez, N. 2009. Multiproxy reconstruction of the palaeoclimate and palaeoenvironment of the middle Miocene Somosaguas sites (Madrid, Spain) using herbivore dental enamel. Palaeogeography, Palaeoclimatology, Palaeoecology, 272, 53-68.

Domingo, L., García Merino, M., Hernández Fernández, M., Grimes, S.T. \& López-Martínez. 2010. Record of the Early and Middle Miocene climatic events on mammalian tooth enamel $\delta^{13} \mathrm{C}$ values from Europe. 70th Anniversary Meeting of the Society of Vertebrate Paleontology, Abstract Book, p. 82A.

Domingo, L., Koch, P.L., Grimes, S.T., Morales, J. \& LópezMartínez, N. 2012. Isotopic paleoecology of mammals and the Middle Miocene Cooling event in the Madrid Basin (Spain). Palaeogeography, Palaeoclimatology, Palaeoecology, 339-341, 98-113.

Domingo, L., López-Martínez, N. \& Grimes, S.T. 2007. Application of trace elements $(\mathrm{Ba}, \mathrm{Sr}, \mathrm{Zn})$ to paleoecological reconstruction of Middle Miocene herbivores at Somosaguas site (Madrid, Spain). 67th Annual Meeting of the Society of Vertebrate Paleontology, Abstract Book, p. 69A.

Élez, J. 2005. Aplicación GIS 3D a los yacimientos paleontológicos de Somosaguas. Diploma de Estudios Avanzados, Universidad Complutense de Madrid (unpublished).

Fesharaki, O. 2005. Mineralogía y Sedimentología del yacimiento Paleontológico de Somosaguas (Mioceno, Cuenca de Madrid). Diploma de Estudios Avanzados, Universidad Complutense de Madrid (unpublished).

Fesharaki, O., García-Romero, E., Cuevas-González, J. \& López-Martínez, N. 2007. Clay mineral genesis and chemical evolution in the Miocene sediments of Somosaguas, Madrid Basin, Spain. Clay Minerals, 42, 187-201.

García Yelo, B., Gómez Cano, A.R., Sanisidro, O., Domingo, L. \& Hernández Fernández, M. 2010. Approximation to the dimensions of the Middle Miocene Iberian savannas. 70th Anniversary Meeting of the Society of Vertebrate Paleontology, Abstract Book, p. 94A.

González, E., Pino, M., Recabarren, O., Canales, P., Salvadores, L., Chávez, M., Bustos, C., Ramos, P., Busquets, T., Vásquez, F. \& Navarro, X. 2011. Paleontología Social: una experiencia educativa sobre ciencia, patrimonio e identidad. Calidad en la Educación, 34, 231-245. 
Hernández Fernández, M. 2008. Aplicación social de la Paleontología: el Proyecto Somosaguas como caso práctico en el Mioceno medio de Madrid. I Reunión Paleontológica Internacional sobre el Breal de Orocual, Caracas (Venezuela).

Hernández Fernández, M., Cárdaba, J. A., Cuevas-González, J., Fesharaki, O., Salesa, M.J., Corrales, B., Domingo, L., Élez, J., López Guerrero, P., Sala-Burgos, N., Morales, J. \& López-Martínez, N. 2006. Los yacimientos de vertebrados del Mioceno medio de Somosaguas (Pozuelo de Alarcón, Madrid): implicaciones paleoambientales y paleoclimáticas. Estudios Geológicos, 62, 263-294.

Hernández Fernández, M., Salesa, M.J., Sánchez, I.M. \& Morales, J. 2003. Paleoecología del género Anchitherium Von Meyer, 1834 (Equidae, Perissodactyla, Mammalia) en España: evidencia a partir de las faunas de macromamíferos. Coloquios de Paleontología, volumen extraordinario, 1, 253-280.

López-Martínez, N., Castilla, G., Cuevas, J., Élez, J., Fesharaki, O., Polonio, I., Salesa, M.J. \& Torices, A. 2005. Gestión e investigación en Somosaguas (Pozuelo de Alarcón, Madrid): Un yacimiento mioceno de vertebrados en el campus de la Universidad Complutense. XXI Jornadas de la Sociedad Española de Paleontología, Abstract Book, p. 14-15.

López-Martínez, N., Élez, J., Hernando, J.M., Luis, A., Mazo, A., Mínguez Gandú, D., Morales, J., Polonio, I., Salesa, M.J. \& Sánchez, I. 2000a. Los fósiles de vertebrados de Somosaguas (Pozuelo, Madrid). Coloquios de Paleontología, 51, 69-86.

López-Martínez, N., Élez, J., Hernando, J.M., Luis, A., Mínguez, D., Polonio, I., Salesa, M.J., Mazo, A. \& Sánchez, I. 2000b. Los vertebrados fósiles de Somosaguas (Pozuelo de Alarcón, Madrid). In: Patrimonio Paleontológico de la Comunidad de Madrid (ed. Morales, J.). Consejería de Educación de la Comunidad de Madrid, 130-140.

Luís, A. 2003. Aplicación de la rarefacción al yacimiento de microvertebrados de Somosaguas (Pozuelo de Alarcón, España). Tesis de Licenciatura, Universidad Complutense de Madrid (unpublished).

Luís, A. \& Hernando, J.M. 2000. Los microvertebrados fósiles del Mioceno Medio de Somosagus Sur (Pozuelo de Alarcón, Madrid, España). Coloquios de Paleontología, 51, 87-136.

Mazo, A.V. 2000. Presencia de Gomphotherium angustidens (Cuvier) (Proboscidea, Mammalia) en el yacimiento de Somosaguas (Pozuelo de Alarcón, Madrid). Coloquios de Paleontología, 51, 175-182.

Menéndez Gamella, A., Serrano, H., Presumido, M. Cárdaba, J.A. \& Fesharaki, O. 2010. Yacimientos paleontológicos de Húmera (Mioceno medio, Cuenca de Madrid): Datos preliminares en Estratigrafía y Paleontología. Cidaris, 30, 187-196.

Mínguez Gandú, D. 2000. Marco estratigráfico y sedimentológico de los yacimientos paleontológicos miocenos de Somosaguas (Madrid, España). Coloquios de Paleontología, 51, 183-196.
Perales, R., Serrano, H., García Yelo, B.A. \& Hernández Fernández, M. 2009. Inferencias paleoambientales del Mioceno medio de Somosaguas (Pozuelo de Alarcón, Madrid) basadas en la estructura de tamaños corporales de su fauna de mamíferos. Paleolusitana, 1, 317-325.

Pérez-García, A. in press. Systematic diversity of the turtles from the Middle Miocene (MN5) of Somosaguas (Pozuelo de Alarcón, Madrid, Spain). Spanish Journal of Palaeontology.

Pérez González, S., Cantalapiedra, J.L., Alcalde, G.M. \& Hernández Fernández, M. 2009. Análisis de los patrones de coloración en bóvidos (Ruminantia, Artiodactyla): aplicaciones en la paleorreconstruction de Tethytragus Azanza \& Morales, 1994. Paleolusitana, 1, 373-382.

Pina, M., Pérez de los Ríos, M. \& Hernández Fernández, M. 2008. Paleocorología de los mamíferos del Mioceno medio de Somosaguas (Pozuelo de Alarcón, Madrid). In: Palaeontologica Nova (eds. Esteve, J. \& Meléndez, G.). Publicaciones del Seminario de Paleontología de Zaragoza, 8, 345-356.

Polonio, I. \& López-Martínez, N. 2000. Análisis tafonómico de los yacimientos de Somosaguas (Mioceno Medio, Madrid). Coloquios de Paleontología, 51, 235-266.

Sala-Burgos, N. \& Gil-Pita, R. 2006. Automatic microfossil detection in Somosaguas Sur paleontologic site (Pozuelo de Alarcón, Madrid, Spain) using multilayer perceptrons. Transactions on Signal Processing, 2, 218-223.

Sala-Burgos, N., Cuevas-González, J. \& López-Martínez, N. 2007. Estudio paleopatológico de una hemimandíbula de Tethytragus (Artiodactyla, Mammalia) del Mioceno medio de Somosaguas (Pozuelo de Alarcón, Madrid). Coloquios de Paleontología, 57, 7-14.

Salesa, M.J. \& Morales, J. 2000. La fauna de carnívoros del yacimiento Aragoniense de Somosaguas (Pozuelo de Alarcón, Madrid). Coloquios de Paleontología, 51, 213-222.

Salesa, M.J. \& Sánchez, I.M. 2000. Estudio de los restos de Anchitherium Meyer, 1834 (Equidae; Perissodactyla) del yacimiento de Somosaguas (Pozuelo de Alarcón, Madrid). Coloquios de Paleontología, 51, 197-212.

Sánchez, I.M. 2000. Rumiantes (Mammalia, Artiodactyla) del yacimiento de Somosaguas (Aragoniense medio, Madrid, España). Coloquios de Paleontología, 51, 223-234.

Torices, A., Bolea, B. \& Cuevas-González, J. 2004. Paleontología Social. II Encuentro de Jóvenes Investigadores en Paleontología, Abstract Book, p. 4647.

Torroba, J., Gómez de la Peña, L., Gómez Cano, A.R., López Guerrero, P. \& Hernández Fernández, M. 2010. Estudio de los patrones de mortandad de Democricetodon larteti (Schaub, 1925) en el yacimiento mioceno de Somosaguas (Pozuelo de Alarcón, Madrid). Cidaris, 30, 325-328.

Van der Made, J. \& Salesa, M.J. 2004. Early remains of the pig Conohyus simorrensis from the Middle Aragonian of Somosaguas near Madrid -its dispersal into Europe and evolution. Neues Jahrbuch für Geologie und Paläontologie, 233, 153-168. 